\author{
E. Pérez ${ }^{\mathrm{a}}$ \\ M.A. Barnadas ${ }^{\mathrm{a}}$ \\ V. García-Patos ${ }^{\text {a }}$ \\ C. Pedro ${ }^{\mathrm{C}}$ \\ R. Curell $^{\mathrm{b}}$ \\ C.A. Sander ${ }^{\mathrm{d}}$ \\ P. Kind ${ }^{\mathrm{d}}$ \\ J.M. de Moragas a \\ A. Alomar ${ }^{\mathrm{a}}$ \\ Departments of \\ Dermatology and \\ b Pathology, Hospital de la Sta. Creu i St. Pau, and \\ Department of Haematology, \\ Clínica de Salud La Alianza, Barcelona, Spain, \\ and \\ d Department of Dermatology, LMU, \\ Munich, Germany
}

\section{Kaposi's Sarcoma in a Patient with Erythroblastopenia and Thymoma: Reactivation after Topical Corticosteroids}

\author{
Key Words \\ Kaposi's sarcoma $\cdot$ Female $\cdot$ Erythroblastopenia $\cdot$ Thymoma $\cdot$ Corticosteroids $\cdot$ HHV-8
}

\begin{abstract}
We report a 69-year-old female with erythroblastopenia and thymoma who developed lesions of Kaposi's sarcoma (KS) after thymectomy, 2 months after the initiation of therapy with methylprednisolone. Control of mucocutaneous KS lesions was obtained with radiotherapy, interferon alfa-2b and withdrawal of systemic immunosuppressive therapy. Erosive oral lichen planus appeared later, and after therapy with topical corticosteroids a new lesion of KS developed that regressed after withdrawal of topical corticosteroids. The detection of HHV-8 only in lesional skin supports the hypothesis that this virus can trigger the development of KS lesions.
\end{abstract}

\section{Introduction}

Kaposi's sarcoma (KS) is a multicentric neoplasm with several manifestations, different clinical features, evolution and degrees of malignancy. Clinical forms include classical $\mathrm{KS}$, endemic KS, epidemic KS and KS in immunosuppressed patients. In all of those variants, HHV-8 has been documented [1].

We report a patient who presented KS after diagnosis of erythroblastopenia and thymoma treated with thymectomy and corticosteroids. HHV-8 was observed only in lesional tissues.

\section{Case Report}

A 69-year-old Spanish female came to our department in July 1993 because of the appearance of violaceous papules, nodules and plaques on the legs, trunk, and upper limbs over the last 5 months.

Medical history revealed that she had been diagnosed with erythroblastopenia and thymoma in December 1992. She underwent thymectomy, and therapy with methylpred- nisolone $40-80 \mathrm{mg} /$ day was initiated in January 1993. She required monthly blood transfusions, and cyclosporine at a dose of $5 \mathrm{mg} / \mathrm{kg} /$ day was initiated in July 1993.

Physical examination revealed violaceous papules, nodules and plaques on her lower limbs that were very painful and were accompanied by edema (fig. 1). Other papules were present on the abdomen, chest, back and oral mucosa.

The histopathological study from a lesion of the chest (biopsy No. 1) revealed a vascular proliferation of mature vessels, together with a proliferation of spindle cells that were present between the spindle cells (fig. 2). The diagnosis of a KS was established, and radiotherapy was initiated on the lower limbs with subsequent resolution of the lesions. In September 1993, corticosteroids and cyclosporine were withdrawn and interferon alfa$2 \mathrm{~b}, 15$ million units per weeks, was initiated, and residual hyperpigmentation was observed 4 months later.

In January 1994, painful, diffuse oral ulcerations appeared. The histopathological study showed a lichenoid infiltrate (biopsy arranged in fascicles. Red blood cells were
No. 2) (fig. 3). Two direct immunofluorescence tests were negative. A diagnosis of erosive lichen planus was established, and therapy with the topical application of $0.1 \%$ triamcinolone acetonide was begun. One month later, a violaceous papule appeared on the dorsum of the tongue. The biopsy confirmed the diagnosis of KS (biopsy No. 3) (fig. 4). Topical corticosteroids were stopped, and no new KS lesions appeared. Different therapies were established with topical anesthetics, nystatine plus fluconazole, chloroquine, spiramycin and griseofulvin without response. Topical cyclosporine was also prescribed, but only a transient improvement was obtained. An erythematous papule appeared inside an ulcerated area, and the histopathological study only showed the presence of granulation tissue (biopsy No. 4).

Laboratory investigation revealed persistent anemia with hemoglobin 50-60 g/l, total lymphocytes 1,756 , with CD4 439 (N 300-3,000), CD8 966 (N 150-2,400), and a CD4/CD8 ratio 0.45 (N 0.8-2.7). Abnormal liver function tests, with AST $68 \mathrm{U} / 1$ (N 9-25), ALT 149 U/1 (N 8-36), alkaline phos-

\section{KARGER \\ Fax+41613061234 E-Mail karger@karger.ch} www.karger.com
(C) 1998 S. Karger AG, Basel

1018-8665/98/1973-0264\$15.00/0

Accessible online at: http://BioMedNet.com/karger
Dr. María A. Barnadas

Department of Dermatology, Hospital de la Sta. Creu i St. Pau C/St. Antoni $\mathrm{M}^{\mathrm{a}}$ Claret, 167

E-08025 Barcelona (Spain)

Tel. +34932919013, Fax +34932919136 

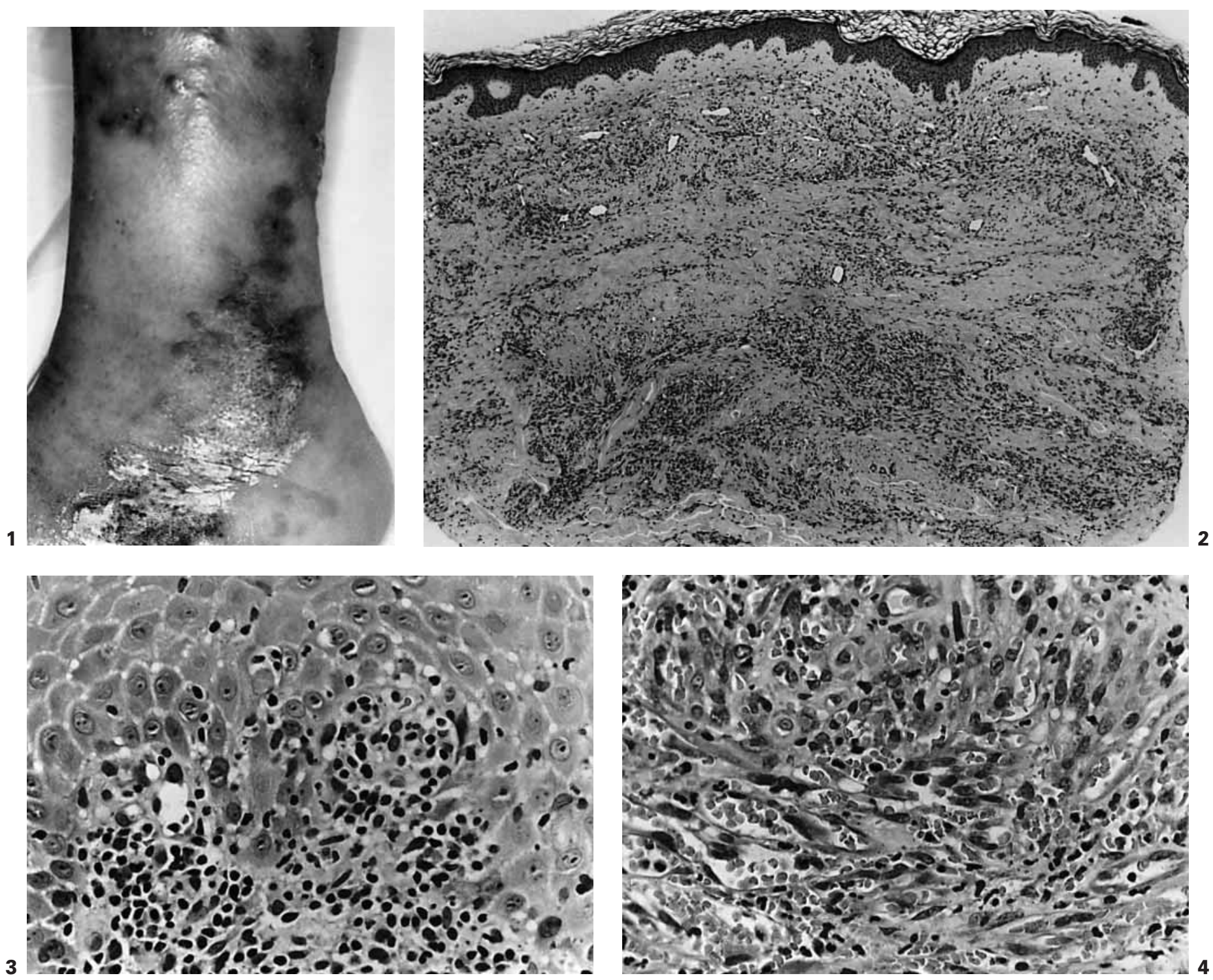

Fig. 1. Papules and nodules of $\mathrm{KS}$ affecting the lower limbs.

Fig. 2. Histopathological study of biopsy No. 1 shows diffuse proliferation of spindle cells in the reticular dermis with mature dilated vessels. HE. $\times 40$.

Fig. 3. Histopathological study of biopsy No. 2 from oral ulceration shows a lichenoid dermatitis. HE. $\times 400$.

Fig. 4. Histopathological study of biopsy No. 3 (the papule of the tongue) shows proliferation of spindle cells with extravasation of red blood cells. HE. $\times 400$.

phatase 516 (N 82-198) U/1, $\gamma$-GTP 172 U/l (N 7-43). Serological tests for hepatitis C virus and HIV were negative. Indirect immunofluorescence test using guinea pig esophagus as substrate was negative.

In October 1995, the patient died due to myocardiopathy secondary to hemosiderosis as a result of multiple transfusions.

Reactivation of KS after

Topical Corticosteroids

\section{Virological Studies}

A PCR amplification for HHV-8 using DNA isolated from paraffin blocks of the four biopsies was performed according to the technique previously published by Simon et al. [2]. Biopsies of KS from the skin and from the tongue (No. 1,3) displayed a PCR amplifi- cation of approximately 233 bp. Southern blot hybridization confirmed the results obtained by the UV visualization of the PCR products in the agarose gel in these cases. Biopsies of oral lichen planus and granulation tissue (No. 2, 4) were negative (these studies were performed by C.A.S.). 


\section{Discussion}

We think that several factors play a role in the development of KS in the patient reported here, such as the presence of thymoma, erythroblastopenia, and the previous therapy with corticosteroids.

KS has been reported in association with a second neoplasm in $37 \%$ of the cases [3]. Lymphoproliferative disorders are the most frequently observed (60\%) [3]. Several cases of KS associated with thymoma have been reported in the literature [4-13]. The interval between thymoma diagnosis and KS appearance ranges from a few months to 6 years. As in our case, some of these patients had been treated with thymectomy and/or immunosuppressive therapy before KS developed [4-13]. Coexisting KS and thymoma have been related to myasthenia gravis, immunosuppressive therapy, CD4+ lymphopenia [12] and increase of CD8+ T lymphocyte counts [11]. This imbalance between CD4+ and $\mathrm{CD} 8+\mathrm{T}$ lymphocytes has been considered responsible for the immunosuppression in patients with thymoma [12].

In our patient, immunosuppressive drugs may also have played an important role in the development of KS, as has been described in patients following corticosteroid therapy for autoimmune disorders (alone or associated with other immunosuppressants) [14-19], solid organ transplantation [20] and other disorders without any underlying neoplastic or autoimmune disease [14, 19, 21-25]. Erythroblastopenia is considered an autoimmune disorder and is associated with thymoma in over $50 \%$ of the patients. Other autoimmune disorders have been associated with KS in the literature [14-19], the most frequent being pemphigus, rheumatoid arthritis, and autoimmune hemolytic anemia.

We suggest that corticosteroids probably played a more significant role in the development of KS than cyclosporine in our patient because: (1) cyclosporine was initiated 5 months after the development of KS lesions, and (2) KS developed on the tongue 1 month after the topical application of $0.1 \%$ triamcinolone acetonide for oral lichen planus, and no new lesions appeared after withdrawal of this therapy.

It is difficult to prove that interferon alfa$2 \mathrm{~b}$ alone was responsible for improvement of the lesions. Immunosuppressive treatment was withdrawn in parallel with interferon $a l f a-2 b$ initiation, and we have found reports of spontaneous improvement after immuno- suppressive therapy was discontinued [14]. In our patient, oral lichen planus appeared during therapy with interferon alfa- $2 b$. Interferon alfa-2a and $-2 b$ have been used to treat heapatitis caused by the hepatitis $\mathrm{C}$ virus. Both interferon alfa- $2 a$ and $-2 b$ have been reported to either initiate [26-28] or exacerbate $[29,30]$ lichen planus lesions following this therapy for infection with hepatitis $\mathrm{C}$ virus. On the contrary, other publications describe clearance [31] or no effect [32] using interferon alfa-2a on oral lichen planus.

Knowledge of HHV-8 has contributed to the understanding of KS. This virus has been detected in KS lesions of all types. Sequences of HHV-8 have also been detected in the uninvolved skin of KS patients in about $35 \%$ of cases and $3 \%$ of control S. HHV-8 may be a widespread latent virus which predisposes to $\mathrm{KS}$, but cofactors such as immunosuppression may be required to develop the disease [1]. The fact that in our patient HHV-8 was detected in KS lesions of the skin and tongue but not in lichen planus lesions or granulation tissue from the oral mucosa supports the hypothesis that this virus plays a role in the development of KS lesions.

\section{References}

1 Fife K, Bower M: Recent insights into the pathogenesis of Kaposi's sarcoma. Br J Cancer 1996;73:1317-1322.

2 Simon M, Kind P, Kaudewitz P, Graf A, Schirren CG, Raffeld M, Sander CA: Detection of herpesvirus-like DNA in HIV-associated and classial Kaposi's sarcoma. Arch Dermatol Res 1996;288:402-404.

3 Safai B, Miké V, Giraldo G, Beth E, Good RA: Association of Kaposi's sarcoma with second primary malignancies: Possible etiopathogenic implications. Cancer 1980;45:1472-1479.

4 Reynolds WA, Winkelmann RK, Soule EH: Kaposi's sarcoma: A clinicopathologic study with particular reference to its relationship to the reticuloendothelial system. Medicine (Baltimore) 1965;44:419-443.

5 Gellin GA: Kaposi's sarcoma: Three cases of which two have unusual findings in association. Arch Dermatol 1966;94:92-94.

6 Maberry JD, Stone OJ: Kaposi's sarcoma with thymoma. Arch Dermatol 1967;95:210-213.

7 Souadjian JV, Silverstein MN, Titus JL: Thymoma and cancer. Cancer 1968;22:1221-1225.

8 Val-Bernal JF, Palacios S, Rodríguez Castro J: Timoma y sarcoma de Kaposi. Patología 1980; 13:253-259.
9 Ulbright TM, Santa Cruz DJ: Kaposi's sarcoma: Relationship with hematologic, lymphoid, and thymic neoplasia. Cancer 1981; 47:963-973

10 Snyder RA, Schwartz RA: Telangiectatic Kaposi's sarcoma. Occurrence in a patient with thymoma and myasthenia gravis receiving long-term immunosuppressive therapy. Arch Dermatol 1982;118:1020-1021.

11 Alcoba Leza M, Cabreros Pisonero E, Menéndez Gutiérrez ML: Sarcoma de Kaposi como segunda neoplasia en el timoma. Rev Clín Esp 1987; 180:520-521.

12 Sawai T, Tuchikawa K: Kaposi's sarcoma developed in a patient with a thymoma in the setting of excess numbers of CD-8 positive cells in the peripheral blood. Arch Pathol Lab Med 1990;114:611-613.

13 Moysset I, Lloreda J, Miguel A, Vadell C, Ribalta T, Estrach T, Serrano S: Thymoma associated with CD4+ lymphopenia, cytomegalovirus infection, and Kaposi's sarcoma. Hum Pathol 1997;28:1211-1213.

14 Trattner A, Hodak E, David M, Sandbank M: The appearance of Kaposi sarcoma during corticosteroid therapy. Cancer 1993;72: 1779-1783.
15 Amblard P, Reymond JL, Sotto JJ, Couderc P Maladie de Kaposi au cours des états dysimmunitaires. Nouv Presse Méd 1978;7: 122-123.

16 Casoli P, Tumiati B: Rheumatoid arthritis, corticosteroids therapy and Kaposi's sarcoma: A coincidence? A case and review of literature. Clin Rheumatol 1992;11:432-435.

17 Hortelano E, Calvo J, Liñana JJ, GonzálezCruz MI, Soler JJ, Fontbuena M: Sarcoma de Kaposi visceral y cutáneo en paciente con artritis reumatoide en tratamiento esteroideo. An Med Intern 1994;11:77-79.

18 Carmeli Y, Mevorach D, Kaminski N, Raz E: Regression of Kaposi's sarcoma after intravenous immunoglobulin treatment for polymyositis. Cancer 1994;73:2859-2861.

19 Casoli P, Tumiati B: Kaposi's sarcoma, rheumatoid artritis and immunosuppressive and/or corticosteroid therapy. J Rheumatol 1992;19:1316-1317.

20 Abel EA: Cutaneous manifestations of immunosuppression in organ transplant recipients. J Am Acad Dermatol 1989;21:167-179. 
21 Nikkels AF, Collignon J, Moutschen MP, Paquet $\mathrm{P}$, Bouillenne C, Piérard GE: Maladie de Kaposi chez une patiente souffrant d'une immunodéficience acquise VIH négative. Presse Méd 1994;23:1760-1761.

22 Bruet A, Mahe A, Sei JF, Mathe C, Felsenheld C, Lechevalier L, Fendler JP: Sarcome de Kaposi compliquant une corticothérapie au long cours pour asthme sévère. Rev Méd Interne 1990;11:322-324.

23 Krussmann A, Goerg R, Laberke HG, Weidne FO: Ausgedehnt metastasiertes Kaposi-Sarkom bei chronisch immunsupprimiertem Bronchialasthma. Hautarzt 1993;44:232-234.

24 Carlesimo M, Giustini S, Rossi A, Bonaccorsi $\mathrm{P}$, Calvieri S: Treatment of cutaneous and pulmonary sarcoidosis with thalidomide. J Am Acad Dermatol 1995;32:866-869.
25 Corda L, Benerecetti D, Ungari M, Facchetti F, Rafaeli E: Kaposi's disease and sarcoidosis. Eur Respir J 1996;9:383-385.

26 Barreca T, Corsini G, Franceschini R, Gambini C, Garibaldi A, Rolandi E: Lichen planus induced by interferon-alpha-2a therapy for chronic active hepatitis C. Eur J Gastroenterol Hepatol 1995;7:367-368.

27 Nunez M, Miralles ES, de las Heras ME, Ledo A: Appearance of oral erosive lichen planus during interferon alfa-2a therapy for chronic active hepatitis C. J Dermatol 1995;22: 461-462.

28 Schlesinger TE, Camisa C, Gay JD, Bergfeld WF: Oral erosive lichen planus with epidermolytic hyperkeratosis during interferon alfa-2b therapy for chronic hepatitis $\mathrm{C}$ virus infection. J Am Acad Dermatol 1997;36: 1023-1025.
29 Areias J, Velho GC, Cerqueira R, Barbedo C, Amaral B, Sanches M, Massa A, Saraiva AM Lichen planus and chronic hepatitis C: Exacerbation of the lichen under interferon-alpha-2a therapy. Eur J Gastroenterol Hepatol 1996; 8:825-828.

30 Heintges T, Frieling T, Goerz G, Niederau C: Exacerbation of lichen planus but not of acute intermittent hepatic porphyria during interferon therapy in a patient with chronic hepatitis C. J Hepatol 1994;21:1152-1153.

31 Lapidoth M, Arber N, Ben-Amitai D, Hagler J: Successful interferon treatment for lichen planus associated with chronic active hepatitis due to hepatitis C virus infection. Acta Derm Venereol 1997;77:171-172.

32 Daoud MS, Gibson LE, Daoud S, el-Azhary RA: Chronic hepatitis $\mathrm{C}$ and skin diseases. Mayo Clin Proc 195;70:559-564. 